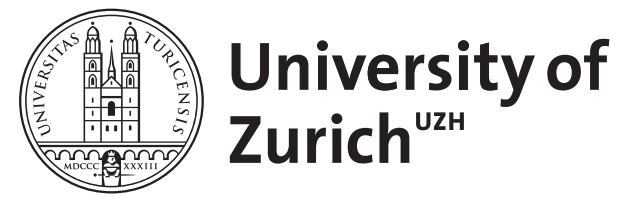

Zurich Open Repository and Archive

University of Zurich

University Library

Strickhofstrasse 39

CH-8057 Zurich

www.zora.uzh.ch

Year: 2006

Healing unhealthy Hungarian hearts-at what cost?-With what benefit?

Szucs, T D

DOI: https://doi.org/10.1007/s10557-006-0041-6

Posted at the Zurich Open Repository and Archive, University of Zurich

ZORA URL: https://doi.org/10.5167/uzh-18581

Journal Article

Published Version

Originally published at:

Szucs, T D (2006). Healing unhealthy Hungarian hearts-at what cost?-With what benefit? Cardiovascular Drugs and Therapy, 20(4):239-43.

DOI: https://doi.org/10.1007/s10557-006-0041-6 


\title{
Healing Unhealthy Hungarian Hearts - At What Cost? - With What Benefit?
}

\author{
Thomas D. Szucs
}

Published online: 4 October 2006

(C) Springer Science + Business Media, LLC 2006

Talpra magyar, hí a haza !

Itt az idõ, most vagy soha!

Rabok legyünk, vagy szabadok?

Ez a kérdés, válasszatok!

A magyarok istenére

Esküszünk,

Esküszünk, hogy rabok tovább

Nem leszünk !

Rise up, Magyar, the country calls!

It's 'now or never' what fate befalls...

Shall we live as slaves or free men?

That's the question - choose your 'Amen'!

God of Hungarians,

we swear unto Thee,

We swear unto Thee - that slaves we shall

no longer be!

\section{- Sandor Petöfi, Hungarian Poet, 1823-1849}

In this journal, Scuffham \& Kósa present a costeffectiveness analysis of the statin fluvastatin in patients following successful percutaneous coronary interventions [1]. The country of reference for this analysis was Hungary, a country which had a more than 40 years experience with a communistic regime, undergoing major transformations in the healthcare system. Recently, the country has joined the European Union. Economic thinking was slowly changing in order to adopt a new more liberal and more open, market-driven system. Economic thinking in health

T. D. Szucs $(\bowtie)$

Institute of Social- and Preventive Medicine,

University of Zurich, Hirschengraben 84,

CH-8001 Zurich, Switzerland

e-mail: Thomas.szucs@ifspm.unizh.ch care is reaching a turning point and issues of resource allocation and prioritization are reaching a new dimension gaining increasing central attention. In this stage of development, economic analyses of health care technologies and health care technology assessment have become an important area of interest. Thus, we may applaud the Hungarians for yielding an increasing number of such interventions, such as the present study by Scuffham \& Kosa.

When scholars such as me occasionally get asked by editors-in-chief of scientific journals to write an editorial on an original piece of work, I usually encounter three distinct situations. First, I might realise that the paper to be discussed is a kind of paper which cannot be understood without the accompanying, clarifiying and educating comments of an expert. Second, I might feel that the paper is of such controversial content, that the editor (and the readers too) require a balanced counter-argumentation of the findings and the conclusions. Third, the paper may exert high quality, be well-conducted, according to international guidelines for economic analyses in health care, convey a balanced view and, to a great deal, speak for itself. In this instance an editorial would clearly be superfluous. I felt that I stood in front of the latter situation. So, what to do? Somehow I did not want to disappoint my editor-in-chief and felt obliged to obey by deciding to write on three topics. First, the health of Hungarians is currently and has not always been in great shape. I needed to discuss this situation and focus on cardiovascular health. This is important for local cardiovascular public health policy makers. Second, I wanted to present some highlights on the Hungarian health system and the utilisation of interventional cardiovascular procedures. This is im- 
portant for health care providers. Third, economic analyses in Hungary are fairly new and deserve their place in the system. I wanted to discuss their increasingly important role. This is important for health economists. Last, but not least, having had a Hungarian father myself, who conveyed to me the love to the people and products of his home country, I felt obliged and honoured to put my thoughts to paper. Hence, I confirmed to my editor-in-chief.

\section{The health of Hungarians}

While the system resembling many of its broad features those of other OECD countries, Hungarians have the lowest life expectancy in the OECD and its rate of increase over the last 20 years has been much slower than in the rest of the area [2]. (Table 1). Between 1930 and 1960 life expectancy at birth rose by more than 20 years in many OECD countries, as it did in Hungary. Since then, progress has been less rapid, with life expectancy increasing by 8.7 years between 1960 and 1990 in the OECD area but only 1.3 years in Hungary; and male life expectancy has actually been falling. As a result, Hungary now has the lowest life expectancy in the area. Outcomes are poor for all agesex groupings but especially for males between 40 and 60 years of age, whose total life expectancy of 68.8 years is seven years less than the OECD average of 75.9 years and is lower than it was in 1930. Female life expectancy is also the lowest among OECD countries, although it has been rising, and is much higher than for males, the gap between them having more than doubled from 4.4 to 9.1 years between 1960 and 1998 . Although it is too soon to know if it represents a temporary improvement or a new positive long-term trend, since 1995 the life expectancy at birth of males has started to increase.

Over-work, poor diet, alcohol and tobacco addiction, unfulfilling work, falls in relative income and growing income inequalities, as well as feelings of relative disadvantage compared with western Europe are considered to be the principal factors contributing to high prime-age male mortality both now and in the 1970s and 1980s. Alcoholism has been cited as an important source of Hungarian mortality and Hungary has the third highest consumption rates in the OECD. The incidence of smoking is also high; 44 per cent of men and 27 per cent of women smoke (the fifth and eighth highest rates in the OECD). Spending on alcohol and tobacco products represent about twenty per cent of total food expenditures with the poorest 10 per cent of the population spending as much as 7.3 per cent of their income on these products. Although total caloric intake per capita is around the OECD average, the traditional Hungarian diet relies excessively on foods with a high fat and sugar content, both of which constitute serious health hazards. Deaths per capita from associated diseases exceed OECD averages by a wide margin, with Hungarians having the highest mortality rates in the area for cancers of the respiratory tract, heart diseases and cirrhosis of the liver. (Table 2).

Table 1 Key data on Hungarian health care system 2003

\begin{tabular}{|c|c|c|c|c|c|c|}
\hline Variable & Hungary & Poland & Czech Republic & Slovakia & Germany & UK \\
\hline Age $>65$ years $(\%)$ & 15.4 & 12.9 & 13.9 & 11.5 & 17.7 & 16 \\
\hline Life expectancy at birth (years) & 72.4 & 74.7 & 75.3 & $73.9^{\mathrm{a}}$ & 78.4 & 78.5 \\
\hline Acute beds/1000 inhabitants (n) & 5.9 & 5.1 & 6.5 & 5.9 & $6.6^{\mathrm{a}}$ & 3.7 \\
\hline Acute beds, occupancy rates ( $\%$ ) & 77.2 & $77.0^{\mathrm{a}}$ & 73.9 & 65.4 & $80.1^{\mathrm{a}}$ & 85.1 \\
\hline Average length of stay, acute (days) & 8.4 & $7.9^{\mathrm{a}}$ & 10.9 & 8.7 & $10.9^{\mathrm{a}}$ & 8.1 \\
\hline THCE, \% of GDP & $7.8^{\mathrm{a}}$ & $6.0^{\mathrm{a}}$ & 7.5 & 5.9 & 11.1 & $7.7^{\mathrm{a}}$ \\
\hline THCE per capita,US\$ PPP & $1115^{\mathrm{a}}$ & 677 & 1298 & 777 & 2996 & $2231^{\mathrm{a}}$ \\
\hline Alcohol consumption (1/day) & $13.4^{\mathrm{a}}$ & $8.1^{\mathrm{a}}$ & 12.1 & 7.6 & 10.2 & 11.2 \\
\hline Calories/d $\mathrm{d}^{\mathrm{b}}$ & 3483 & 3375 & 3171 & 2889 & 3496 & 3412 \\
\hline$\%$ of population $>15 \mathrm{yrs}$, smoking & 33.8 & $27.6^{\mathrm{b}}$ & $24.1^{\mathrm{a}}$ & 24.3 & 24.3 & 26.0 \\
\hline $\mathrm{BMI}>25$ & 52.8 & $\mathrm{n} / \mathrm{a}$ & $51.1^{\mathrm{a}}$ & $57.6^{\mathrm{a}}$ & 49.2 & $62^{c}$ \\
\hline
\end{tabular}

a 2002

b 2001

${ }^{\mathrm{c}}$ different methodology

GDP: Gross domestic product

THCE: totla health care expenditure

PPP: purchasing parity index

BMI: body mass index in $\mathrm{kg} / \mathrm{m}^{2}$ 
Table 2 Key indicators of interventional cardiology

\begin{tabular}{|c|c|c|c|c|c|c|}
\hline Indicator & Hungary & Poland & Czech Republic & Slovakia & Germany & UK \\
\hline Coronary angiograms $/ 10^{6}$ inhabitants [7] & 1651 & 1393 & 2971 & 1047 & 7344 & 2544 \\
\hline PTCAs $/ 10^{6}$ inhabitants & 251 & 504 & 927 & 193 & 2226 & 590 \\
\hline Drug eluting stent rate (\%) & 35 & 45 & 36 & 27 & 32 & 29 \\
\hline PCIs per angiogram ratio & 0.15 & 0.36 & 0.31 & 0.18 & 0.3 & 0.23 \\
\hline Stenting/PTCA & 0.79 & 0.44 & 0.66 & 0.51 & 0.68 & 0.8 \\
\hline
\end{tabular}

\section{Key features of the Hungarian health care system}

The Hungarian health system is relatively resource intensive and is characterised by high hospitalisation rates, an excess supply of specialists and perverse incentives both for doctors and hospital administrators. Budgetary rules prevent hospitals from properly amortising investments and limit their capacity to manage labour costs. Furthermore inadequate supervision of billing by the state administrator has led to a fraudulent inflation in both the number and the "seriousness" of treatments. Recent reforms have concentrated on containing costs but efforts to improve service delivery and health outcomes have been plagued by problems of institutional conflict. Although cost pressures on the healthcare system are likely to intensify in the future, the economy's capacity to pay will improve and, as a result, the gap between the quality and quantity of Hungarian versus European healthcare will gradually close.

Hungary has a comprehensive insurance-type health care system, based on the principle of social solidarity. Accordingly, compulsory contributions by employees are paid according to earnings, rather than individuals' health risks. Coverage is close to universal in terms of treatments provided, with virtually all citizens benefiting from the service whether they contribute or not. Within this context, however, the system is now radically different from that in place at the beginning of the 1990s, a reflection of the wide ranging structural reforms introduced. In particular, it is no longer as strongly integrated in the state sector and operates under a purchaser-provider approach.

Hungary's measured expenditures on healthcare are, as a share of GDP, among the lowest in the OECD. In absolute terms, its spending is 7.8 of the gross domestic product and is about half the level of Spain and Portugal and only 38 per cent of the OECD average. In terms of per capita public expenditures, relative position of Hungary has worsened both compared to the OECD average and to the less developed OECD countries. In this context, the increase in pharmaceutical expenditures has been considered a major health policy problem. However, data show that the observed spending pattern is not that different from that observed in other lower income OECD countries and is converging to this norm.

One area where spending discipline will become increasingly important in Hungary is health care. Reforms need to consider ways to make financing more stable and sustainable. The slow progress in modernising the health care system is reflected in the low efficiency of hospitals, excessive recourse to inpatient care and heavy prescription of drugs by doctors.

Eastern European transitional countries have the highest mortality rates from cardiovascular diseases in Europe. In 2001, the standardized death rates (per 100,000 inhabitants) from cardiovascular diseases for men and women aged 0-64 were 212.1 in Ukraine, 176.0 in Bulgaria, and 149.8 in Romania. In contrast, these death rates were the lowest in economically stable countries, such as France, Spain, and the Netherlands (31.2, 35.4, and 41.6 per 100,000 inhabitants [3]. In Hungary, the standardized cardiovascular death rate was 175 per 100,000 in 1991 and 121 per 100,000 in 2003. The corresponding figures for Europe were 117 and 122. In ischemic heart disease, the standardized death rates in Hungary were $85 / 100,000$ in 1991 and 59/100,000 in 2003. The corresponding figures across Europe were 81 and 80.

Since the first percutaneous transluminal coronary angioplasty (PTCA) performed in 1977, the number of PCIs has increased dramatically, with more than 733,000 now performed annually in Europe [4]. The mean population-adjusted rate in 2003 was 1283 procedures per $10^{6}$ inhabitants, which is a $5 \%$ increase from 2002. Germany reported the highest number (2522/106 inhabitants) whereas Romania reported the lowest number (152/106 inhabitants). The highest relative increases were observed in Greece $(+70 \%)$, Slovakia $(+50 \%)$, Poland $(+50 \%$ and Hungary $(+46 \%)$. About $35 \%$ of all PCI uses drug eluting stents. Table 2 and Fig. 1 give an overview of key indicators of interventional cardiology and their development in Hungary and in comparison to other countries. 
Fig. 1 Development of angiographies and interventional procedures in Hungary and Europe 1992-2001.

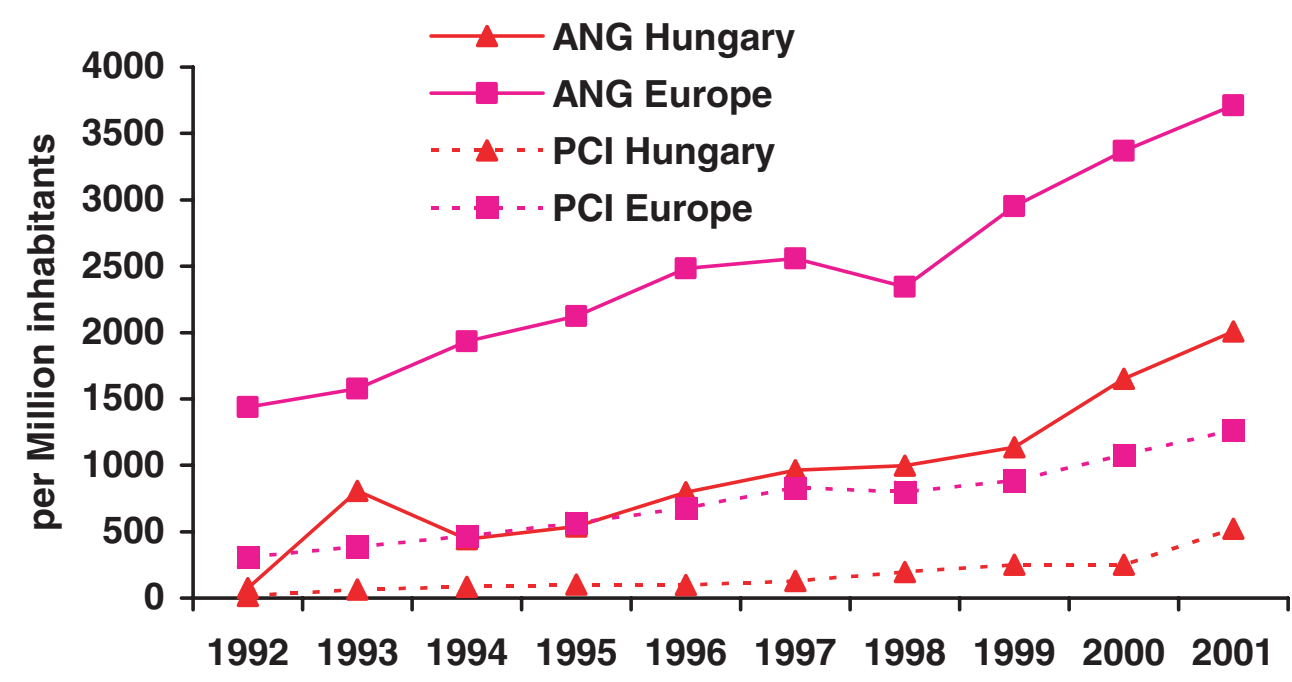

What did the LIPS study show and what can we learn from health economics?

The LIPS study is the first prospective trial in patients undergoing their first PCI with clinical outcomes as the primary end point [5]. Patients enrolled in our study generally had an earlier CHD stage (all had unstable or stable angina or silent ischemia, and less than half had prior MI) and statin therapy was initiated very early after the index procedure compared with earlier trials. Results of the LIPS study show that in patients with average cholesterol levels, early cholesterollowering treatment with fluvastatin, $80 \mathrm{mg} / \mathrm{d}$, following first PCI with or without stenting resulted in a $5.3 \%$ absolute reduction and a $22 \%$ relative reduction in the risk of fatal or nonfatal major adverse cardiac events during 4 years of follow-up compared with placebo. These results suggest that treating 19 post-PCI patients with fluvastatin for 4 years would prevent 1 fatal or nonfatal MACE (number needed to treat, 19; 95\% CI, 11-82), suggesting benefit similar to that observed in other secondary prevention trials.

Prevention of restenosis and cardiac events in patients who have had percutaneous revascularization is of enormous public health importance. Substantial amounts of effort and monies have been spent on multiple drug strategies, but with limited success.

The fundamental aim of any health care system is to maximize the health and welfare of its population, but because resources will always be scarce in relation to the health care needs, a series of choices must be made. Decision makers responsible for allocating resources need to prioritize between competing uses in order to maximize benefits (or health gains) under budgetary constraints. Prioritization takes place on different levels of the health care system. On the health authority level and senior health plan management level planners decide on the specialty and service mix they wish to purchase for their beneficiaries with the goal to optimize resource allocation to health programs. This allocation process is often a mix of rational thinking and a political agenda. In the increasingly privatized hospital market decisions are made about the purchase of medicines and equipment with the goal to maximize profits. At the level of the individual physicians, prioritization is increasing influenced by medical audits and other forms of peer review, with more clinical guidelines. These constrains usually impose the payers view on the economics of medicines upon individual physicians. This is not to say that it is generally bad to impose such constrains to the health delivery system as long as such decisions are based on solid evidence. Pharmacoeconomics can help to make better informed choices.

In this respect, economic analyses have become important tools to help prioritize health care interventions. The beauty of these analyses is that they make the economic dimension more explicit. In the case of rationing health care, cost-effectiveness analyses may be a fairer and more justified approach, than decision making without empirical evidence. However, it must be stressed that prioritisation must always be based on the prior sound establishment of a technology's clinical effectiveness and safety. Only thereafter, do economic analyses come into play.

The study by Scuffham \& Kosa revealed a costeffectiveness ratio of Euro 15910. Even though there are not yet acknowledged thresholds in Hungary on the level up to which services should be covered by payers, it is common understanding that such a value is well within the range of acceptable cost-utility values in most European countries. Hence, the treatment of 
post-PCI patients with fluvastatin should represent good value for money.

Geoffrey Rose [6] the doyen of preventive cardiology, stated in 1991 that 'all policy decisions should be based on absolute measures of risk; relative risk is strictly for researchers only'. By extrapolation then, risk management for prevention of coronary heart disease should be based on absolute global risk assessment, so that scarce healthcare resources can be targeted at those patients in greatest need. In this respect, we must ask ourselves, if the additional investment of fluvastatin is a worthwhile endeavour. Clearly, Scuffham \& Kosa have given ample evidence that this is the case, not only in the Hungarian health care setting, but also in other countries. It is laudable, that these analyses are also increasingly being compiled not only for economically advance countries, but also less economically developed countries around the globe.

In this sense: ad multas copias.

This piece of mind is dedicated to my beloved father, Dr. Dezso Lajos Szucs (*Budapest 1935+Basel 2005), a true Hungarian in heart and soul.

\section{References}

1. Scuffham PA, Kosa J. The cost-effectiveness of fluvastatin in Hungary following successful percuatneous coronary intervention. Cardiovasc Drugs Ther 2006

2. OECD Health Data 2005. OECD. Credes, Paris, France.

3. Lukenda J, Kolaric B, Kolcic I, Pazur V, Biloglav Z. Cardiovascular diseases in Croatia and other transitional countries: comparative study of publications, clinical interventions, and burden of disease. Croat Med J 2005;46(6): 865-74.

4. Stefane Cook et al. Percutaneous coronary interventions in europe 1992-2003. EuroIntervention. http://www.eurointer vention.org), last accessed, April 29. 2006.

5. Serruys PW, de Feyter P, Macaya C, Kokott N, Puel J, Vrolix M, Branzi A, Bertolami MC, Jackson G, Strauss B, Meier B, Lescol Intervention Prevention Study (LIPS) Investigators. Fluvastatin for prevention of cardiac events following successful first percutaneous coronary intervention: a randomized controlled trial. JAMA 2002;287(24):3215-22.

6. Rose G. Environmental health: problems and prospects. J R Coll Physicians Lond 1991;25:48-52

7. Balmer F, Rotter M, Togni M, Pfiffner D, Zeiher AM, Maier W, Meier B; on behalf of the Working Group Interventional Cardiology and Coronary Pathophysiology of the European Society of Cardiology. Percutaneous coronary interventions in Europe 2000. Int J Cardiol 2005;101(3):457-63. 